\title{
Development of environmental friendly bioinoculate for peanut (Arachis hypogea L.) production in Eastern Ethiopia
}

\author{
Anteneh Argaw*
}

\begin{abstract}
Background: Bacterial bioinoculate is one of environmentally friendly input for crop production. Several works revealed that effectiveness of Rhizobium bioinoculant have been affected by the native rhizobia population. Hence, this study was initiated to evaluate the effect of selected Bradyrhizobium in nodulating peanut in the major growing areas of Ethiopia.

Methods: The effect of eight effective Bradyrhziobium vis-a-vis $20 \mathrm{~kg} \mathrm{~N} \mathrm{ha}^{-1}$ and the control check on the nodulation and yield of two peanut cultivars (Sedi and Werer 942) at Babile and Fedis, eastern Ethiopia, during 2013 cropping season was evaluated.

Results: The results showed that the inoculation, location and cultivar and their two and three ways interaction had a significant influence on the nodulation and grain yield. Inoculation of Bradyrhizobium increased the nodule number, nodule dry weight, number of seeds per plants, total pods weight, hundred seeds weight, total biomass yield, grain yield and shelling \% up to $37,24.9,22.4,22.5,5.5,26.2,35.8$ and $24.1 \%$, respectively. Isolate HUGNR-29 was found to be more effective as it scored the highest nodule dry weight and grain yield. Application of inorganic $\mathrm{N}$ increased the yield and yield components of peanut in either of locations. Though the statistically better effective nodule $\%$ was recorded at Babile, significantly higher nodule number, nodule dry weight, and total $\mathrm{N}$ accumulation were obtained from Fedis than Babile site. Significantly higher total pods weight, hundred seeds weight, total biomass weight, grain yield and total plant $\mathrm{N}$ accumulation was recorded with the cultivar werer-962 than those produced with Bati-Sedi.

Conclusions: The result showed that Bradyrhizobium inoculation is essential to improve the peanut production through environmentally and economically sustainable ways though the soil native rhizobia nodulating peanut was high. Peanut cultivar and study site based rhizobia inoculant development is also important.
\end{abstract}

Keywords: Babile, Bradyrhizobium, Fedis, HUGNR-29, Inoculation

\section{Background}

The peanut is the fourth most widely cultivated oilseed in the America continents, Africa and Asia. Peanut plants grow best in well-drained sandy soils and sunny warm temperatures with moderate rainfall. In Ethiopia, the total planted area was 443000 ha and a production of $103.7 \mathrm{M}$ ton of grain as it has been reported in the 2014 cropping

\footnotetext{
*Correspondence: anteneh.argaw@haramaya.edu.et; antenehargaw@gmail.com

School of Natural Resources Management and Environmental Sciences, College of Agriculture and Environmental Sciences, Haramaya University, Dire Dawa, Ethiopia
}

season (FAOSTAT 2014). This report also showed that the productivity of peanut has been $1604.1 \mathrm{~kg} \mathrm{ha}^{-1}$. To increase this productivity, plant breeder has tried to release new high yielder varieties of peanut in Ethiopia (Kebede and Bushra 2012). So far, peanut varieties improving program in Ethiopian has obtained the peanut variety yielding up to 2.2 ton $\mathrm{ha}^{-1}$. When its productivity is comparing to the productivity $\left(3.25\right.$ ton $\left.\mathrm{ha}^{-1}\right)$ that has been reported in North Carolina is very low (Jones 2003). Hence, improving the production and productivity of peanut in Ethiopia using environmental friendly technologies is essential. 
Peanut is considered a highly promiscuous species because it is nodulated by rhizobia able to nodulate a diverse group of legumes and a large group of unrelated rhizobia (Alwi et al. 1989). For instance, up to $18 \%$ of the tested fast and slow growing rhizobia isolated from cowpea are able to form effective nodules with peanut (Thies et al. 1991; Mpepereki et al. 1996). Several studies have also already shown phenotypically and genetically diverse bradyrhizobia isolates nodulating peanut ( $\mathrm{Li}$ et al. 1999; Zhang et al. 1999). Most commonly reported isolates of bradyrhizobia nodulating peanut are Bradyrhizobium japonicum and Bradyrhizobium elkanii (Willems et al. 2001; Yang et al. 2005; Nievas et al. 2012; Bogino et al. 2010). Peanut is also nodulated by fast-growing rhizobia such as Rhizobium giardini and Rhizobium tropici (Huang 1990; Taurian et al. 2006). The contribution of biological nitrogen fixation (BNF) through peanut-rhizobia symbiosis has been reported as $40.9 \mathrm{~kg} \mathrm{ha}^{-1}$ (Okito et al. 2004).

Abundant types of indigenous rhizobia nodulating peanut are widely distributed in various geographical and ecological areas of the world (Xu et al. 1995; Chen et al. 1997; Tan et al. 1999; Peng et al. 2002). Most cultivated soils of the tropics appear to have relatively large populations ( $>10^{2} \mathrm{~g}^{-1}$ dry soil) of cowpea miscellany which can induce nodules on peanut root (Allen and Allen 1981). My unpublished work showed the presence of native rhizobia nodulating peanut in Ethiopian soils. Hence the indigenous rhizobia may interfere the effectiveness of inoculated effective isolate thereby causes lack of success of inoculation in improving nodulation and $\mathrm{N}_{2}$ fixation of peanut (Hitbold et al. 1983; Kvien and Pallas 1986). However, if the native rhizobia is symbiotically effective, increase in native rhizobia population increased the yield of pulses (Thrall et al. 2007).

The presence of nodules on roots of the peanut plant does not necessarily mean that sufficient $\mathrm{N}_{2}$ is being fixed for maximum growth of the host plant (Weaver 1974; Nambiar et al. 1982a). Inoculation is a major strategy for the development of sustainable input of nitrogen into agricultural soils (Lindström et al. 2010). Inoculation of legume seed is an efficient and convenient way of introducing highly efficient rhizobia to the soil to improve the peanut production (Deaker et al. 2004). Inoculation of Bradyrhizobium peanut resulted in the nitrogen fixation amounting up to $186 \mathrm{~kg} \mathrm{~N} \mathrm{ha}^{-1}$ (Moawad et al. 1986). Castro et al. (1999) found that peanut roots have been well nodulated by native strain rather than the exotic one. Hence, selection of efficient strains based on their local ecologic adaptation can increase grain production of crops (Denton et al. 2003; Lindström et al. 2010; Bianco et al. 2013). On top of differing the rhizobia in their ability to fix $\mathrm{N}_{2}$, the effective peanut-rhizobia symbiosis is the product of rhizobial and plant cultivars as well as of environmental conditions (Nelson 1987; Sessitsch et al. 2002). Manipulating the peanut cultivar and Bradyrhizobium strain together in one system would be the most important for a productive approach to optimizing $\mathrm{N}_{2}$ fixation and increase the peanut productivity (Chen et al. 2003). Hence, the hypothesis of this work was stated that inoculation of rhizobia isolated from native soil improves the nodulation and yield of peanut even though the soil native rhizobia population has been $>10^{2} \mathrm{~g}^{-1}$ soil. Our approach has been to utilize indigenous rather than exotic rhizobia, since the former, already adapted to the existing ecological conditions, can provide very satisfactory results (Douka and Xenoulis 1987; Hungria et al. 1996; Makatiani and Odee 2007). Therefore, the objective this work was to evaluate the symbiotic effectiveness of selected indigenous Bradyrhizobium sp. nodulating peanut in eastern Ethiopia.

\section{Methods}

\section{Description of the study sites}

Field studies were conducted in 2013 cropping season at Fedis $\left(09^{\circ} 06.941^{\prime} \mathrm{N}\right.$ and $042^{\circ} 04.835^{\prime} \mathrm{E}$ at an altitude of $5476 \mathrm{ft}$ above sea level [asl]) and Babile $\left(09^{\circ} 13.234^{\prime} \mathrm{N}\right.$ and $042^{\circ} 19.407^{\prime} \mathrm{E}$ at $5478 \mathrm{ft}$ asl) Agricultural Research Sub-center, Haramaya University, located in the eastern part of Ethiopia. The soils of the study sites (Babile and Fedis) were sandy loam and silty clay loam, respectively. Fedis site receives a mean annual rainfall of $714.3 \mathrm{~mm}$ (Ethiopia Meteorological Report, unpublished), with a mean maximum and minimum temperature of 27.8 and $8.8{ }^{\circ} \mathrm{C}$, respectively. The area has a bi-modal pattern, falling in two seasons, with the short rain season occurring between March and May and the long rain season from between June through October. At Babile site, the annual means maximum and minimum temperatures are 20 and $90{ }^{\circ} \mathrm{C}$, respectively with annual mean rainfall of $540 \mathrm{~mm}$ which has been calculated based on the weather data between 2000 and 2014. The soil of Babile site before planting the experiment showed the following properties: $\mathrm{pH}$ 6.66; EC, $0.04 \mathrm{dS} \mathrm{m}^{-1}$; organic carbon content, $0.56 \%$; total $\mathrm{N}, 0.06 \%$ available $\mathrm{P}$ content (Olsen), $2.22 \mathrm{mg} \mathrm{kg}^{-1}$; contents of exchangeable $\mathrm{K}^{1+}, \mathrm{Ca}^{2+}, \mathrm{Mg}^{2+}$ and $\mathrm{Na}^{1+}, 0.34,4.18,3.5$ and $0.15 \mathrm{cmol}(+) \mathrm{kg}^{-1}$, respectively; cation exchange capacity, $8.17 \mathrm{cmol}(+) \mathrm{kg}^{-1}$, number of rhizobia, $5.8 \times 10^{2}$ cells $\mathrm{g}^{-1}$ of dry soil. The top $20 \mathrm{~cm}$ of Fedis soil contained $1.32 \%$ soil organic C, $0.12 \%$ total $\mathrm{N}, 1.78 \mathrm{mg} \mathrm{kg}^{-1}$ Olsen-P, cation exchange capacity, $37.2 \mathrm{cmol}(+) \mathrm{kg}^{-1}$ and 23.12, 12.87, 0.12 and 1.09 exchangeable $\mathrm{Ca}^{2+}, \mathrm{Mg}^{2+}, \mathrm{Na}^{1+}$ and $\mathrm{K}^{1+}$, respectively, and had a $\mathrm{pH}$ value (in water) of 7.76 and $\mathrm{EC}$ value of $0.06 \mathrm{dS}$ mat $^{-1}$ the start of the experiment. The number of rhizobia nodulating peanut at Fedis soil was $<10^{2}$ viable cell $\mathrm{g}^{-1}$ dry soil. 


\section{Sources of the Bradyrhizobium isolates}

Rhizobial isolates used were recommended Bradyrhizobium sp. for Peanut (Arachis hypogeal L.). The bacteria used in this study were HUGNR-1, HUGNR-2, HUGNR3, HUGNR-4, HUGNR-5, HUGNR-6, HUGNR-7 and HUGNR-8. These isolates were selected because they were previously found efficient isolates in $\mathrm{N}_{2}$ fixation under greenhouse conditions (Akuma 2010).

\section{Sources of the cultivars}

Recently released and high yielder cultivars of peanut (Werer-924 and Sedi) were obtained from lowland oil crop, Haramaya University, Ethiopia.

\section{Preparation of inoculant}

Purity was assured by routine plating on YEM agar supplemented with Congo red and white colony was selected for further use for inoculant production. White colony were transferred into $100 \mathrm{ml}$ containing YEM (yeast extract mannitol) medium in $250 \mathrm{ml}$ Erlenmeyer flasks and incubated at $28{ }^{\circ} \mathrm{C}$ on a shaker incubator at $150 \mathrm{rpm}$. After $48 \mathrm{~h}$ incubation, the number of viable cells in the culture broth was determined by the drop-plate method by counting colony-forming units (CFU) on YEMA plates (Somasegaran and Hoben 1994).

The carrier used for this experiment was decomposed filter cake after sterilized in autoclave at $121{ }^{\circ} \mathrm{C}$. Filter cake based inoculant was prepared by mixing sterilized Filter cake and culture broth at $1: 1 \mathrm{v} \mathrm{w}^{-1}$ under aseptic conditions and placed in an incubator at $25^{\circ} \mathrm{C}$ for 1 week. After inoculation, the population of viable rhizobia cell was reached at $10^{9}$ rhizobia $^{-1}$ of dry peat.

\section{Experimental design and treatments}

Ten treatments comprised of eight elite Bradyrhizobium, $\mathrm{N}$ fertilized $20 \mathrm{~kg} \mathrm{~N} \mathrm{ha}^{-1}$ ) and an absolute control where no external inputs were applied were laid out as a randomized complete block design (RCBD) with three replications. The seeds were planted in $3 \mathrm{~m}$ rows with $10 \mathrm{~cm}$ spacing between plants and $40 \mathrm{~cm}$ between rows. The gross plot size was $3 \times 3 \mathrm{~m}$. Seeds which had been surface wetted, were mixed thoroughly with the peat culture and sown immediately. Triple-superphosphate (46 kg $\mathrm{P}_{2} \mathrm{O}_{5} \mathrm{ha}^{-1}$ ) was uniformly applied for experimental plots. Inorganic $\mathrm{N}\left(20 \mathrm{~kg} \mathrm{~N} \mathrm{ha}^{-1}\right)$ as starter $\mathrm{N}$ was applied only for $\mathrm{N}$-fertilized treatment. All inorganic fertilizer were incorporated in the soil before planting.

\section{Indigenous rhizobial count}

Undamaged and uniform seeds of peanut was sterilized using $0.2 \% \mathrm{HgCl}_{2}$ and $95 \%$ ethanol (Vincent 1970) and then the germination was done in petri-dishes containing wetted filter paper. Three healthy seedlings were transferred to each of pot containing autoclaved sand (Vincent 1970) and thereafter thinned to one seedling per pot. From each soil sample, serial dilutions, ranging from $10^{-1}$ to $10^{-10}$ were prepared and added at a rate of $1 \mathrm{ml}$ per pot. After 6 weeks, the numbers of nodulated plants were recorded and the most probable number (MPN) of rhizobia nodulating peanut was estimated (Brockwell 1963).

\section{Agronomic data collection}

At the late flowering stage at the $\mathrm{R}_{2}$ stage, five plants from internal rows were uprooted for nodulation parameters assessment. The soil adhering to roots and other plant parts was removed under running tap water. The nodules were collected and the dry weight of the plants and nodules were measured after drying the samples at $70{ }^{\circ} \mathrm{C}$ for $72 \mathrm{~h}$. At harvest, plants obtained from $1 \mathrm{~m}^{2}$ were analyzed for yield determinations and the results expressed in $\mathrm{kg} \mathrm{ha}^{-1}$.

\section{Data analysis}

Analysis of variance (ANOVA) was carried out using the randomized block design method. Least significance difference (LSD) was calculated to discriminate the effect treatment on the measured plant traits at $5 \%$ probability.

\section{Results}

\section{Nodulation}

This field inoculation experiment was conducted at Fedis and Babile sites where the native rhizobia of peanut were $2.6 \times 10^{2}$ and $3.3 \times 10^{3}$ rhizobia of peanut $\mathrm{g}^{-1}$ soil, respectively as estimated by the MPN method. The result of the ANOVA showed that the main effect of inoculation (I), locations (L) and cultivar $(\mathrm{C})$ and their two and three ways interaction significantly affected the pooled nodule number $(\mathrm{NN})$ and nodule dry weight $(\mathrm{NDW})$ at $\mathrm{P}<0.05$ (Table 1). However, the effect of cultivar on pooled NN and NDW across locations and $\mathrm{L} \times \mathrm{C}$ interaction effect on pooled NDW were not significant at $\mathrm{P}>0.05$, implying that the performance of the tested cultivar in terms of nodulation in these two locations are similar. This study showed that both cultivars performed equally in NDW production in both experimental locations. The result revealed that Bradyrhizobium inoculation did not improve significantly the pooled NDW compared with not inoculated.

The main effect of location and $\mathrm{C} \times \mathrm{I}$ significantly influenced the \% of effective nodules. This result suggests the presence of different effectiveness of native and inoculated Bradyrhizobium with the cultivar Werer-962 and Bati-Sedi. It was also found various effective nodules \% at Babile and Fedis. Inoculating HUGNR-10 resulted in significantly increase the pooled $\mathrm{NN}$ over the uninoculated 


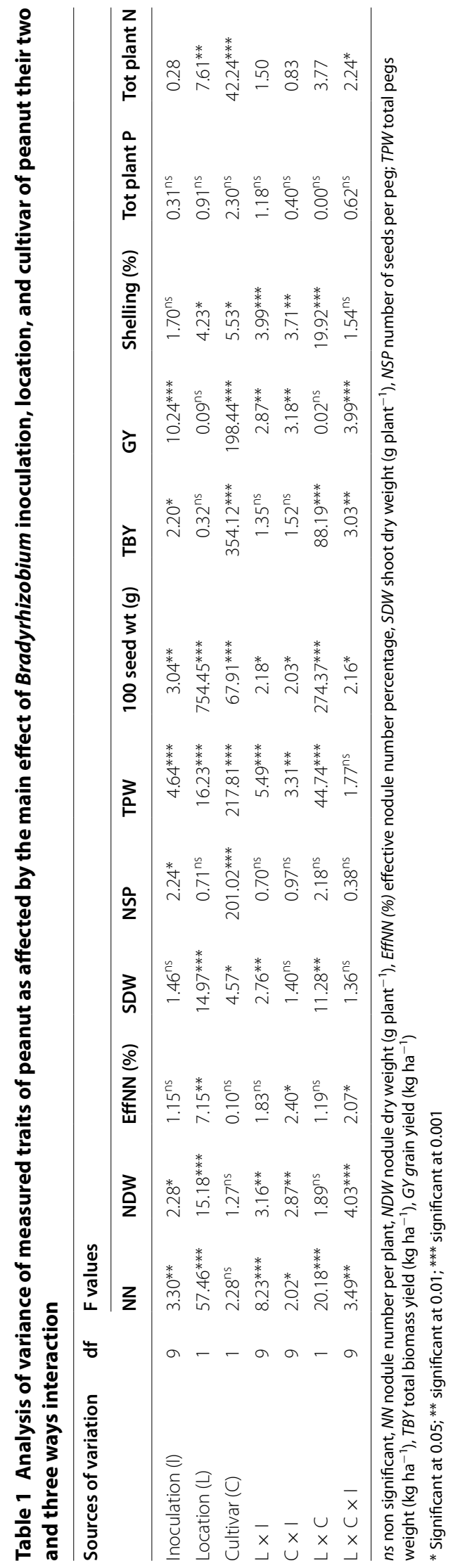


treatment (Table 2). However, inoculation did not affect the $\%$ of the effective nodule, indicating that the indigenous soil Bradyrhizobium sp. was able to induce effective nodules on peanut roots.

In general, the result revealed that significantly higher NN and NDW were found at Fedis than Babile site (Table 2). This could be associated the presence of high peanut rhizobia population and conducive environmental condition for nodulation at Fedis soil when compared to Babile soil. However, significantly higher $\%$ of effective nodules was recorded at Babile site than Fedis site. Both cultivars induced the statistically at par amount of $\mathrm{NN}$, NDW and \% of effective nodules.

All inoculated isolates including $\mathrm{N}$ fertilization except HUGNR-18 significantly increased the effective nodule \% at Babile site (Fig. 1c). It was also found that only HUGNR13 inoculation resulted in significant increase in effective nodule $\%$ at Fedis site. The present work also found that all isolates tested except HUGNR-18 inoculation caused the significant increased in effective nodules \% with Bati-sedi cultivar (Fig. 2c). With Werer-962, a significant increase in effective nodules \% was found due to HUGNR-11 and consortium inoculation and $\mathrm{N}$ fertilization.
The tested Bradyrhizobium showed different performance on NN and NDW production in both locations. At Babile site, except for HUGNR-11, all isolates including $\mathrm{N}$ fertilized plant gave the higher NN than the uninoculated treatment (Fig. 1a). At Fedis site, only HUGNR-11 inoculation resulted in increase in $\mathrm{NN}$ when compared to uninoculated treatment. This different result obtained at two locations may have arisen from higher native rhizobia population at Fedis than Babile site. Beside this, better NDW at Babile site were recorded due to Consortium isolates and HUGNR-29 inoculations but higher NDW than uninoculated at Fedis site due to all inoculation treatments, except HUGNR-10 and HUGNR-19 (Fig. 1b).

When the data stratified by cultivar, most of the tested Bradyrhizobium isolates except HUGNR-11, HUGNR13 and HUGNR-29 improved the NN of the cultivar Werer-962 whilst all isolates inoculation with the cultivar Bati-Sedi cultivar resulted in higher NN than the control check (Fig. 2a). Only HUGNR-29 with werer-962 improved the NDW over the uninoculated treatment (Fig. 2b). The isolates which were resulted in a significantly increased NDW with Bati-Sedi were Consortium isolates, HUGNR-13, HUGNR-18 and HUGNR-29. This

Table 2 Nodulation traits, shoot dry weight, number of seeds per pg and total pegs weight as affected by Bradyrhizobium inoculation, cultivar, and location

\begin{tabular}{|c|c|c|c|c|c|c|}
\hline Treatments & NN & NDW & EffNN (\%) & SDW & NSP & TPW \\
\hline Consortium & $138.75 a b$ & $0.2679 a b$ & $81.25 a$ & $51.7 a$ & 2.89ab & 3384.3abc \\
\hline HUGNR-10 & $158.83 a$ & $0.2703 a b$ & $83.25 a$ & $59.48 a$ & $2.72 a b$ & $3701.4 a$ \\
\hline HUGNR-11 & $121.83 b$ & $0.2332 a b$ & $83.25 a$ & $51.58 a$ & $2.72 a b$ & $3634.3 a$ \\
\hline HUGNR-12 & $137.58 \mathrm{ab}$ & $0.2478 \mathrm{ab}$ & $81.50 a$ & $53.97 a$ & $2.70 a b$ & 3752.3a \\
\hline HUGNR-13 & $126.58 b$ & $0.2417 a b$ & $84.75 a$ & $55.03 a$ & $2.64 a b$ & 3493.1abc \\
\hline HUGNR-18 & 139.17ab & $0.2365 a b$ & $79.42 a$ & $54.81 a$ & $2.58 \mathrm{ab}$ & $3613.4 a$ \\
\hline HUGNR-19 & $134.08 \mathrm{ab}$ & $0.2160 b$ & 79.83a & $50.35 a$ & $3.00 \mathrm{a}$ & $3011.6 c$ \\
\hline HUGNR-29 & 133.00ab & $0.2991 a$ & $85.17 a$ & $57.85 a$ & $2.92 \mathrm{ab}$ & 3553.2ab \\
\hline Uninoculated & $115.75 b$ & $0.2394 a b$ & $79.33 a$ & $50.76 a$ & $2.45 b$ & $3062.5 b c$ \\
\hline N fertillized & 137.08ab & $0.2539 a b$ & $84.50 a$ & $43.84 a$ & $2.86 a b$ & $3518.5 a b c$ \\
\hline Fvalue & $3.30^{* *}$ & $2.28^{*}$ & $1.15^{\mathrm{ns}}$ & $1.46^{\mathrm{ns}}$ & $2.24^{*}$ & $4.64^{* * *}$ \\
\hline $\operatorname{LSD}(P<0.05)$ & 29.54 & 0.0715 & 9.66 & 16.73 & 0.52 & 539.46 \\
\hline Babile & $118.883 b$ & $0.2314 b$ & $84.00 a$ & $57.38 a$ & $2.78 a$ & $3323.15 b$ \\
\hline Fedis & $149.65 a$ & $0.2697 a$ & $80.45 b$ & 48.49b & $2.72 \mathrm{a}$ & $3621.76 a$ \\
\hline F value & $57.46^{* * *}$ & $15.18^{* * *}$ & $7.15^{* *}$ & $14.97^{* * *}$ & $0.71^{\mathrm{ns}}$ & $16.23^{* * *}$ \\
\hline $\operatorname{LSD}(P<0.05)$ & 8.077 & 0.0196 & 2.64 & 4.575 & 0.1428 & 147.52 \\
\hline Werer 962 & $137.33 a$ & $0.2561 \mathrm{a}$ & $82.43 a$ & $50.48 b$ & $2.24 b$ & 4019.44a \\
\hline Bati-Sedi & $131.20 \mathrm{a}$ & $0.2450 \mathrm{a}$ & $82.02 \mathrm{a}$ & 55.39a & $3.26 a$ & $2925.46 b$ \\
\hline F value & $2.28^{\mathrm{ns}}$ & $1.27^{\mathrm{ns}}$ & $0.10^{\text {ns }}$ & $4.57^{*}$ & $201.02^{* * *}$ & $217.81^{* * *}$ \\
\hline $\operatorname{LSD}(P<0.05)$ & 8.08 & 0.0196 & 2.64 & 4.58 & 0.14 & 147.52 \\
\hline CV (\%) & 16.56 & 21.49 & 8.84 & 23.79 & 14.30 & 11.69 \\
\hline
\end{tabular}

Means in the same column followed by the same letter are not significantly different at the $5 \%$ probability level by Tukey's test

ns non-significant, $N N$ nodule number per plant, $N D W$ nodule dry weight (g plant ${ }^{-1}$ ), EffNN (\%) effective nodule number percentage, SDW shoot dry weight (g plant $\left.{ }^{-1}\right), N S P$ number of seeds per peg, TPW total pegs weight $\left(\mathrm{kg} \mathrm{ha}^{-1}\right)$

* Significant at $0.05,{ }^{* *}$ significant at $0.01,{ }^{* * *}$ significant at 0.001 


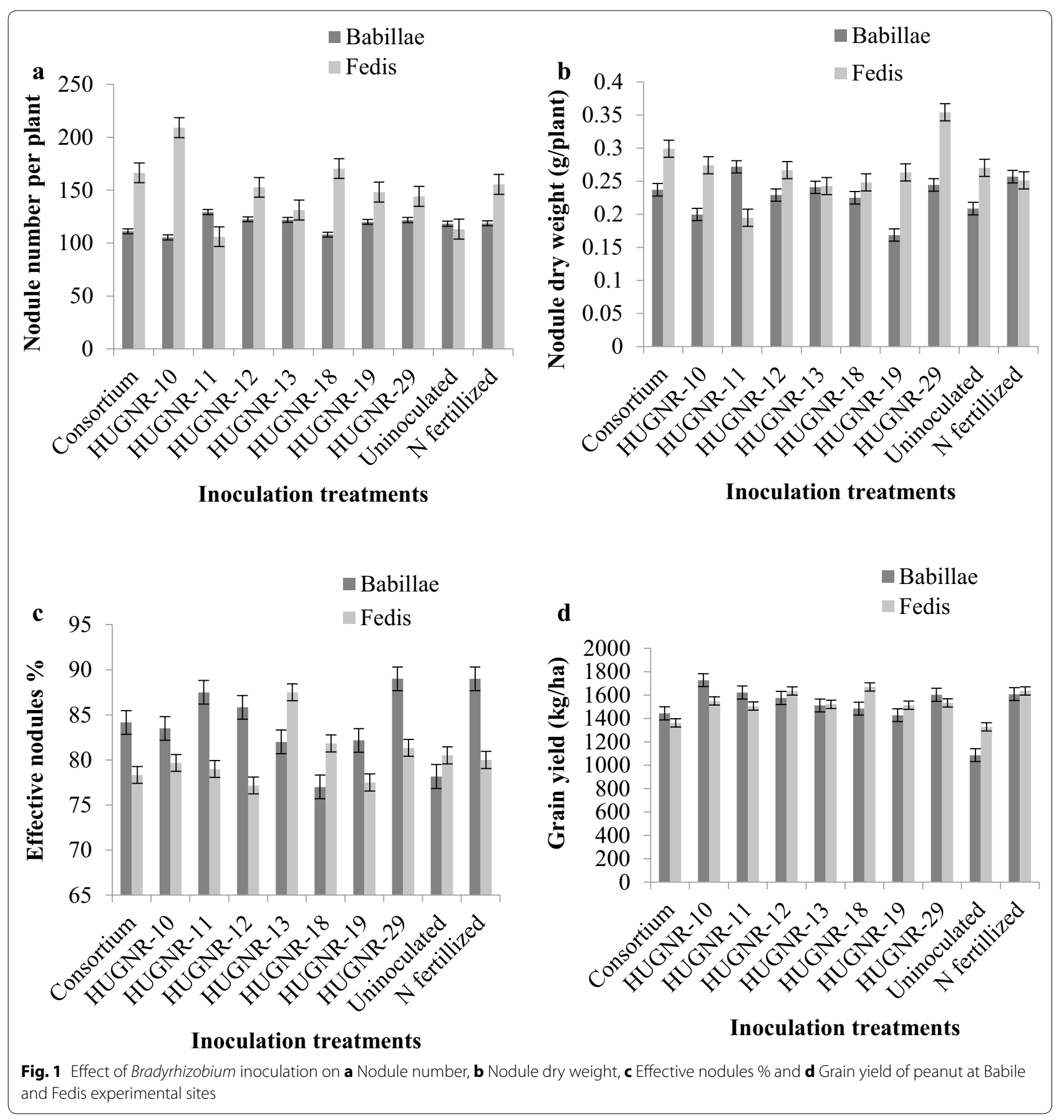

result indicates the permissiveness of the cultivar werer962 for most of the tested isolates.

\section{Shoot dry weight}

The main effect of location and cultivar, and $\mathrm{L} \times \mathrm{I}$ and $\mathrm{L} \times \mathrm{C}$ on the pooled shoot biomass yield produced at late flowering stage across locations were significant at $\mathrm{P}<0.05$ (Table 1 ). Inoculation did not significantly
$(\mathrm{P}>0.05)$ increase the pooled shoot biomass of peanut (Table 2). Significantly higher pooled shoot biomass at the late flowing stage was recorded at Babile site than Fedis site, indicating Babile site could have a favorable condition for peanut as compared to the Fedis. The cultivar Bati-Sedi has recorded significantly higher pooled shoot biomass than the cultivar Werer-962. 


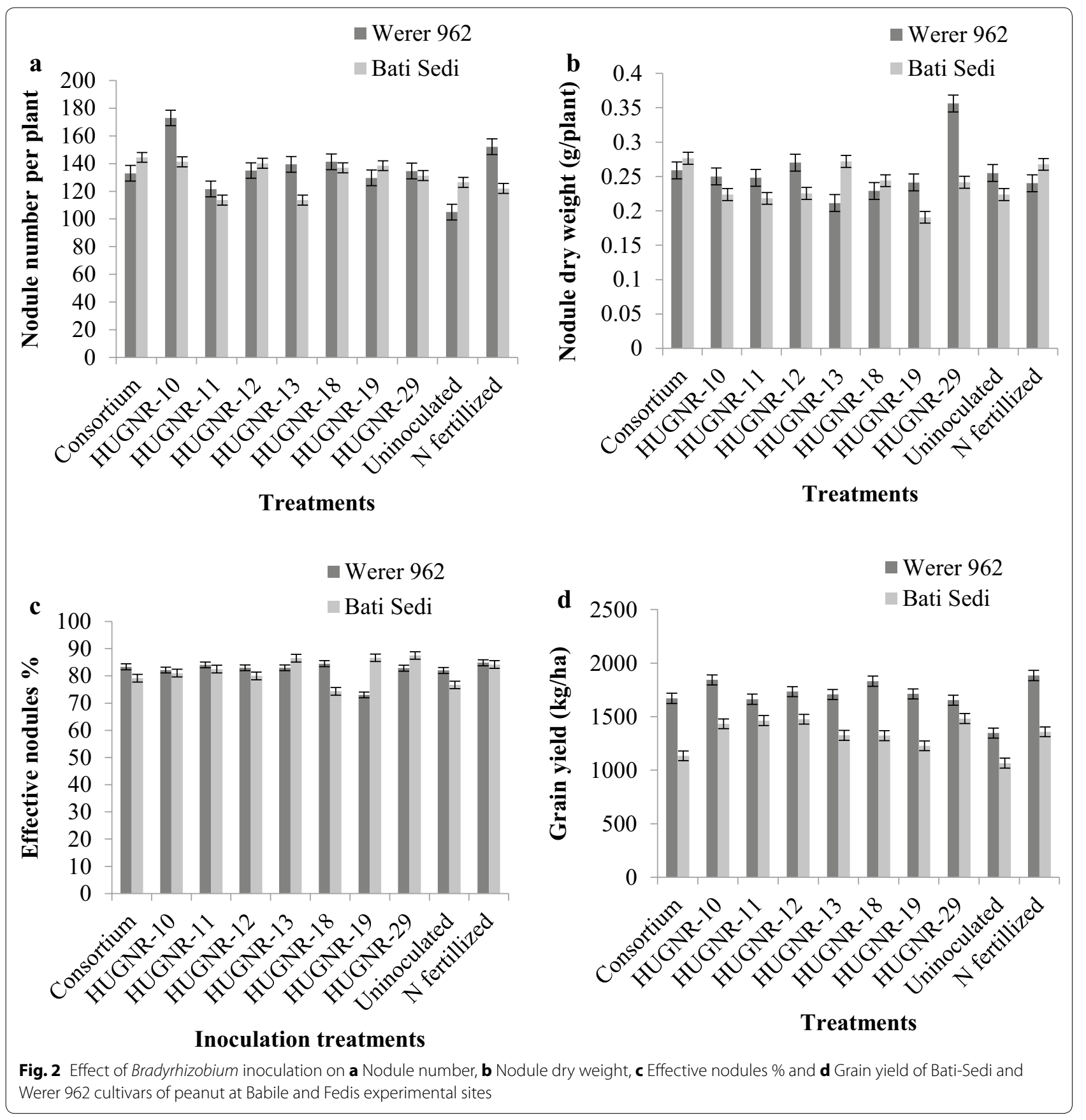

\section{Number of seeds per pod}

The Bradyrhizobium inoculation and cultivar had significant effect on average number of seeds per pod across locations (Table 1). The lower number of seed per pod was measured in the uninoculated treatment. This indicates the need of $\mathrm{N}$ in the form of either inorganic or organic to improve the number of seeds per pod. A significantly higher average number of seeds per pod was recorded with the cultivar Bati-Sedi than the cultivar
Werer-962. However, a number of seed per pod of peanut was not significantly differed which were obtained from two locations.

\section{Total pods weight per hectare}

The main effect of inoculation, cultivar and locations and their two ways interaction significantly varied the pooled total pods weight per hectare across locations (Table 1). Plants inoculated with HUGNR-10, HUGNR-11, 
HUGNR-12 and HUGNR-18 resulted in significantly increased total pod biomass $\left(\mathrm{kg} \mathrm{ha}^{-1}\right)$ as compared uninoculated treatment but did not differ statistically with $\mathrm{N}$-fertilized treatment (Table 2). This implies that these isolate may provide a similar amount of $\mathrm{N}$ as it had been applied $\mathrm{N}$ in the $\mathrm{N}$ fertilized treatment. Inoculating HUGNR-12 increased the total pod's weight by $22.5 \%$ over uninoculated treatment. Significantly higher average total pod weight was recorded at Fedis than Babile site. The cultivar werer-962 produced significantly higher average total pods weight than the cultivar Bati-Sedi.

\section{0 seeds weight}

ANOVA revealed that the main effect and their two and three interaction effect of three factors significantly influenced the pooled hundred seeds weight across locations (Table 1). However, none of the tested Bradyrhizobium isolates did improve significantly $(\mathrm{P}<0.05)$ the pooled hundred seeds weight of peanut. Across the inoculation treatments, Babile site recorded significantly higher hundred seeds weight than Fedis site. The cultivar Werer962 recorded significantly better average hundred seeds weight than the cultivar Bati-Sedi.

\section{Total biomass yield}

The ANOVA revealed that the main effects of inoculation, cultivar, and location and their two ways interaction effect were significant on the pooled total biomass yield per hectare of peanut across locations (Table 1). Inoculating HUGNR-29 significantly increased pooled total biomass yield by $26.2 \%$ compared with uninoculated but this biomass was statistically at par with $\mathrm{N}$-fertilized treatment (Table 3). Both locations produced statistically at par amount of average total biomass yield of peanut. Significantly higher average total biomass yield across inoculation treatments was produced with the cultivar Werer 962 than Bati-Sedi.

\section{Grain yield}

The main effect of inoculation, cultivar and locations and their two and three ways interaction significantly affected the pooled grain yield of peanut across locations (Table 1). However, the main effect of location and $\mathrm{L} \times \mathrm{C}$ did not influence the pooled grain yield, showing that location different did not influence the grain yield production of the tested cultivars of peanut. All Bradyrhizobium inoculation including $\mathrm{N}$ fertilized treatments

Table 3 Hundred seed weight, total biomass yield, grain yield, total plant $\mathbf{N}$ and $\mathbf{P}$ accumulation as affected by Bradyrhizobium inoculation, cultivar, and location

\begin{tabular}{|c|c|c|c|c|c|c|}
\hline Treatments & 100 seed wt & TBY & GY & Shelling (\%) & Tot plant P & Tot plant $\mathrm{N}$ \\
\hline Consortium & $44.01 \mathrm{ab}$ & 7927.1ab & $1402.69 b$ & $41.64 a b$ & $1.4728 \mathrm{a}$ & $3.0489 a$ \\
\hline HUGNR-10 & $45.56 a b$ & 8146.9ab & $1638.56 a$ & $45.85 a b$ & $1.6368 a$ & $3.0733 a$ \\
\hline HUGNR-11 & 44.39ab & $7864.8 a b$ & 1563.75ab & $44.85 a b$ & $1.4471 \mathrm{a}$ & $3.0722 \mathrm{a}$ \\
\hline HUGNR-12 & 45.30ab & $8051.7 a b$ & $1605.16 a$ & 45.10ab & $1.4656 a$ & $2.9494 a$ \\
\hline HUGNR-13 & $42.62 b$ & $8217.5 \mathrm{ab}$ & $1516.45 a b$ & 45.33ab & $1.4259 a$ & $2.9762 \mathrm{a}$ \\
\hline HUGNR-18 & $42.13 a$ & $8070.7 a b$ & $1577.31 \mathrm{ab}$ & $44.86 a b$ & $1.4812 \mathrm{a}$ & $3.0177 a$ \\
\hline HUGNR-19 & $46.26 a$ & $7228.0 \mathrm{ab}$ & 1470.41ab & $50.59 a$ & $1.5505 \mathrm{a}$ & $2.9732 \mathrm{a}$ \\
\hline HUGNR-29 & $44.92 a b$ & $8560.3 a$ & $1609.71 a$ & $46.42 \mathrm{ab}$ & $1.4259 a$ & $3.0078 a$ \\
\hline Uninoculated & 43.82ab & $6782.5 b$ & $1206.95 c$ & $40.77 b$ & $1.3763 a$ & $2.9594 a$ \\
\hline N fertillized & 44.87ab & 7391.9ab & $1622.07 a$ & $47.11 a b$ & $1.3935 a$ & $3.0506 a$ \\
\hline F-value & $3.04^{* *}$ & $2.20^{*}$ & $10.24^{* * *}$ & $1.70^{\text {ns }}$ & $0.31^{\text {ns }}$ & $0.28^{\mathrm{ns}}$ \\
\hline LSD $(P<0.05)$ & 2.95 & 1657.9 & 191.42 & 9.65 & 0.6426 & 0.4103 \\
\hline Babile & $50.36 a$ & $7729.8 a$ & $1517.25 a$ & $46.61 a$ & $1.4255 a$ & $2.9351 b$ \\
\hline Fedis & $39.22 b$ & $7858.5 a$ & $1525.30 a$ & $43.89 b$ & $1.5096 a$ & $3.0907 a$ \\
\hline F-value & $754.45^{* * *}$ & $0.32^{\mathrm{ns}}$ & $0.09^{\mathrm{ns}}$ & $4.23^{*}$ & $0.91^{\mathrm{ns}}$ & $7.61^{* *}$ \\
\hline LSD $(P<0.05)$ & 0.81 & 453.36 & 52.34 & 2.64 & 0.1757 & 0.1122 \\
\hline Werer 962 & $46.46 a$ & $9937.6 a$ & $1706.54 a$ & $43.69 b$ & $1.4006 a$ & $3.1961 \mathrm{a}$ \\
\hline Bati-Sedi & $43.12 b$ & $5650.7 b$ & $1336.02 b$ & $46.81 a$ & $1.5345 a$ & $2.8297 b$ \\
\hline F-value & $67.91^{* * *}$ & $354.12^{* * *}$ & $198.44^{* * *}$ & $5.53^{*}$ & $2.30^{\text {ns }}$ & $42.24^{* * *}$ \\
\hline LSD $(P<0.05)$ & 0.81 & 453.36 & 52.34 & 2.64 & 0.1757 & 0.1122 \\
\hline CV (\%) & 4.96 & 16.00 & 9.47 & 16.04 & 32.96 & 10.25 \\
\hline
\end{tabular}

Means in the same column followed by the same letter are not significantly different at the 5\% probability level by Tukey's test

ns non-significant, $T B Y$ total biomass yield $\left(\mathrm{kg} \mathrm{ha}^{-1}\right) ; G Y$ grain yield $\left(\mathrm{kg} \mathrm{ha}^{-1}\right)$

* Significant at $0.05 ;{ }^{* *}$ significant at $0.01 ;{ }^{* * *}$ significant at 0.001 
produced significantly higher pooled grain yield than the uninoculated treatment (Table 3). In both experimental locations, all Bradyrhizobium inoculation including $\mathrm{N}$ fertilization were found to increase the grain yield production (Figs. 1d, 2d). Moreover, all inoculation treatment including $\mathrm{N}$ application with both cultivars gave the higher grain yield than uninoculated.

Inoculating HUGNR-10 and HUGNR-29 plants were found to increase the pooled grain yield by 35.8 and $33.45 \%$ over the uninoculated treatment, respectively. When compared to the uninoculated, fertilization with $\mathrm{N}$ increased the grain yield by $34.5 \%$. The difference in pooled grain yield production between two locations was not statistically significant at $\mathrm{P}>0.05$. The cultivar Werer-962 recorded significantly higher pooled grain yield than the cultivar Bati-Sedi.

\section{Shelling \%}

Except for the main effect of inoculation, and three-way interaction, the remaining main and interaction effect on pooled shelling \% of peanut was significant at $\mathrm{P}<0.05$ (Table 1). Inoculations and $\mathrm{N}$ application increased significantly the shelling percentage of a peanut compared with uninoculated (Table 3). Averaged across the inoculation treatments, significantly higher shelling $\%$ was recorded at Babile site than Fedis site. The cultivar BatiSedi was found to have significantly higher shelling \% than Werer-962.

\section{Total plant $\mathrm{N}$ and $\mathrm{P}$ concentration}

The ANOVA revealed that none of the main and their interactions was affect significantly $(\mathrm{P}>0.05)$ the total plant $\mathrm{P}$ concentration (Table 1). However, the main effect of location, cultivar and three ways interaction effect on pooled total plant $\mathrm{N}$ concentration was significant $(\mathrm{P}<0.05)$. Inoculation had no significant effect on pooled plant $\mathrm{N}$ concentration, showing that indigenous and inoculated Bradyrhizobium could have been a similar efficacy in $\mathrm{N}_{2}$ fixation. Averaged total $\mathrm{N}$ plant concentration of peanut across the inoculation treatments at Fedis site was found to be significantly higher than that obtained from Babile site. The cultivar werer-962 accumulated significantly higher average plant tissue $\mathrm{N}$ than Bati-Sedi.

\section{Discussion}

Use of inoculants in Ethiopia for food legume production including peanut is very infant. Due to low productivity of peanut in Ethiopia, enhancing the peanut-rhizobia symbiosis thereby improve the productivity using inoculation of effective rhizobia is essential. The native rhizobia population, the host genotypes and environmental condition are the major factors affecting the efficacy of inoculated rhizobia. The soil of the study sites had the native rhizobia capable of nodulating peanut greater than $10^{2} \mathrm{~g}^{-1}$ of soil. Large number of native rhizobia in the two soils could be because of the presence of conducive soil properties (Yousef et al. 1987; Thrall et al. 2007; Drew et al. 2012) and cultivating the host plant for long time (Chemining'wa and Vessey 2006; Kimiti and Odee 2010). However, the previous experiment conducted this region showed that inoculation of locally isolated rhizobia improved the yield of common bean (Anteneh 2016), Fababean (Argaw et al. 2012a) and Field pea (Argaw et al. 2012b), though the soil had $>10^{3}$ rhizobia $^{-1}$ soil. Therefore, this study was initiated to evaluate locally isolated Bradyrhizobium effectiveness on the productivity of peanut at major production areas of eastern Ethiopia.

Despite the natural rhizobia population has been large enough in the experimental soils, inoculation of selected isolated of native Bradyrhizobium significantly increased the pooled nodule number. However, the result revealed that inoculation did not affect significantly the pooled nodule dry weight and $\%$ of effective nodules of peanut Similarly, effective indigenous Bradyrhizobium isolate did not increase nodulation when the native rhizobia were abundant (Okogun and Sanginga 2003; Denton et al. 2009). On top of this, the present study found the non-significant effect of inoculation on pooled shoot dry weight, total plant $\mathrm{N}$ accumulation, and total $\mathrm{P}$ concentration. This result clearly indicated that the native rhizobia effective in supplying $\mathrm{N}$ to host plants as the inoculated isolates did. In line with this result, Kremer and Peterson (1983) found that the $\mathrm{N}_{2}$ fixation by peanut has been only increased when the inoculation improved the nodule weight.

When the data was stratified by location, at Fedis site, of tested isolates, consortium isolates and HUGNR-29 inoculating plants had significantly higher NDW than the uninoculated plants. At Babile site, except HUGNR-18, all tested isolates including $\mathrm{N}$ application increased significantly the NDW and \% of the effective nodule. In line with this finding, inoculation of Rhizobium on promiscuous legume plants increased nodulation (Valladares et al. 2002). However, few numbers of tested rhizobia found effective at Fedis site could be associated with the presence of competitive and high rhizobia population nodulating peanut in the experimental soil. Similarly, Wielbo et al. (2012) highlighted that soil type and the host plant identity influenced the competitiveness of rhizobia. Competitive ability of rhizobia strains also determined by the metabolic potential in utilizing a diversity carbon and energy sources of tested isolates and the responsiveness of nod genes to flavonoid activation (Wielbo et al. 2007; Maj et al. 2010). 
All isolates of Bradyrhizobium significantly increased the nodule number of the cultivar Werer-962 while a significant increase of this trait for the cultivar Bati-Sedi was found when inoculated with Consortium isolates, HUGNR-10, HUGNR-12, HUGNR-18 and HUGNR-19. Only HUGNR-29 inoculation increased the significantly nodule dry weight of the cultivar Werer-962. Effective nodules $\%$ of the cultivar Werer-962 significantly improved by isolate HUGNR-18 inoculation. The difference in strain survival, growth, and competition in the rhizosphere, the production of appropriate plant and bacterial signals might have been the causes of the difference in compatibility of tested isolated with tested cultivars of peanut (Wollum 1998). This observation was in agreement with the findings of Chen et al. (2003) that there has been peanut cultivars-Bradyrhizobium strain specificity in Argentina soil. With cultivar Bati-Sedi, most of the tested Bradyrhizobium increased the nodule dry weight and \% of effective nodules. With regards to inorganic $\mathrm{N}$ application, the significant increased nodule dry weight and \% of effective nodules found with BatiSedi but did not found with Werer-962. This indicates the variance effect of $\mathrm{N}$ application on nodulation of the two tested cultivars of peanut. This finding is confirmed by Abdel Wahab and Abd-Alla (1996) with soybean and showed that Soybean cv. Crawford showed a greater response to the low rate of $\mathrm{N}$ than cv. Clark.

The result of the present work has highlighted that inoculating HUGNR-29 was effective in significantly improving the pooled NDW and \% of effective nodules. This isolate also improved the pooled total biomass and grain yield of peanut, indicating the need of inoculation for improving the effective nodule and production of peanut in the study sites as has been reported by Huang (1987). On top of this, all tested Bradyrhizobium inoculation including inorganic $\mathrm{N}$ application significantly increased the grain yield of peanut at Fedis and Babile sites. The positive effect of $\mathrm{N}$ application might be associated the presence of low concentration of nitrate in both soils which could act as an additional source of nitrogen until the plant start $\mathrm{N}_{2}$ fixation (Becana and Sprent 1987). However, the result showed that yield increases with inorganic $\mathrm{N}$ application was not statistically at par with HUGNR-29 inoculation, implying that Rhizobium inoculation can substitute the external inorganic $\mathrm{N}$ application. Elkan (1992) reported that the rhizobia-peanut symbiosis can derive $\mathrm{N}$ from the atmosphere as much as $152 \mathrm{~kg} \mathrm{~N} \mathrm{ha}^{-1}$ which is $80 \%$ of the plant of the protoplasmic nitrogen. Moreover, about $55 \%$ of the plant N needs of peanut are delivered from the air via nitrogen fixation (Hardarson 1993).

The averaged nodule number and dry weight and total plant $\mathrm{N}$ accumulation across the inoculation treatments at Fedis were found to be significantly higher than those obtained from Babile. This difference could be because of the environmental conditions such as the effectiveness and competitiveness of the native rhizobia, soil condition and weather condition prevailed during the experimental time at both locations. Räsänen and Lindström (1999) found the different ability of isolate HAMBI2180 nodulating Acacia Senegal due to different soil temperature. The result the currect work found the non-significant difference in averaged \% of effective nodules, total biomass and grain yield across the inoculation treatments which were recorded at Fedis and Babile. This indicates that indigenous rhizobia in Fedis and Babilale sites may have been similar effectiveness in $\mathrm{N}_{2}$ fixation and supplying $\mathrm{N}$ to the plant.

It was also found the non-significant difference in nodule number and dry weight and \% of effective nodules recorded between the cultivar Werer-962 and Bati-Sedi. This finding is in line with the study on peanut cultivars (van Rossum et al. 1994) that had similar nodulation in neutral soil $\mathrm{pH}$ condition. It has been reported previously by Alwi et al. (1989) who tested 29 Bradyrhizobium against 16 cultivar of peanut and found that some of the isolates were effective with varieties and other showed a degree of specificity with cultivar. Chen et al. (2003) demonstrated that Bradyrhizobium displayed a varying degree of effectiveness, with some isolates being fairly effective with all tested cultivars and others with selected ones.

Despite the variation in nodulation, significantly higher averaged total pods weight, 100 seeds weight, total biomass and grain yield and shelling \% across the inoculation treatments were found with Werer-962 than Bati-Sedi. These differences could have been due to inherent productivity potential difference between the two tested cultivars of peanut. Barbour et al. (1992) found that nodulation and $\mathrm{N}_{2}$ fixation by peanut varieties are found to be heritable and controlled by genetic make of the host plant. In the current work, the cultivar Werer-962 accumulated significantly higher plant $\mathrm{N}$ concentration than the cultivar Bati-Sedi. This $\mathrm{N}$ concentration difference between the cultivars could have been because of the fact that biomass production of the cultivar werer-962 was greater than the cultivar BatiSedi which cause variation in $\mathrm{N}_{2}$ fixation. Peoples et al. (2001) highlighted that 20-25 kg of shoot $\mathrm{N}$ has been fixed for every tone of legume shoot dry weight accumulated. Ankomah et al. (1996) found out that the good correlation between shoot $\mathrm{N}$ concentration and $\mathrm{N}_{2}$ fixation. In addition, the variation of $\mathrm{N}$ accumulation might also be related with inherent property of the tested peanut cultivars as has been reported by Nambiar and Dart (1980). 


\section{Conclusions}

It is evident from the results of this study that inoculation of Bradyrhizobium is necessary in order to improve nodulation and seed yields of peanut. This result also revealed that the need of location and cultivar specific selection of Bradyrhizobium for better production of peanut in the study locations. It has been also found that $\mathrm{N}$ applied at starter rate requires to improve the yield of peanut. Further work is needed to determine whether combined application of $\mathrm{N}$ with Bradyrhizobium or/and their sole application can improve the peanut productivity in the study site. Moreover, multi-locational trials are required to check their effectiveness for the other agro-climatic conditions to give concrete conclusive to use the isolate as a candidate for national biofertilizer production.

\section{Acknowledgements}

This work was funded by the Ethiopian Institute Agricultural Research, Peanut Improvement Project. A special thanks to the field assistant for invaluable help with data collection and processing in both the field and the laboratory.

\section{Competing interests}

The author declare no competing interests.

\section{Availability of data and materials}

Not applicable.

\section{Consent for publication}

Not applicable.

\section{Ethics approval and consent to participate}

Not applicable.

\section{Publisher's Note}

Springer Nature remains neutral with regard to jurisdictional claims in published maps and institutional affiliations.

Received: 11 February 2017 Accepted: 19 September 2017

Published online: 29 September 2017

\section{References}

Abdel Wahab AM, Abd-Alla MH (1996) Effect of different rates of N-fertilizers on nodulation, nodule activities and growth of two field grown cvs. of soybean. Fertilizer Res 43:37-41

Akuma A (2010) Evaluation of symbiotic effectiveness of rhizobia (Bradyrhizobium spp. L.) with groundnut (Arachis hypogaea L.) in Eastern Harerghe zone of Oromiya regional state, Ethiopia. MSc. Thesis, Haramaya University, Haramaya, Ethiopia

Allen ON, Allen EK (1981) Leguminosae. University of Wisconsin Press, USA, pp 60-64

Alwi N, Wynne JC, Rawlings JO, Schneeweis TJ, Elkan GE (1989) Symbiotic relationship between Bradyrhizobium strains and peanut. Crop Sci 29:50-54

Ankomah AB, Zapata F, Hardarson G, Danso SKA (1996) Yield, nodulation, and $\mathrm{N}_{2}$ fixation by cowpea cultivars at different phosphorus levels. Biol Fertil Soils 22:10-15

Argaw A (2016) Effectiveness of Rhizobium inoculation on common bean productivity as determined by inherent soil fertility status. J Crop Sci Biotechnol 19(4):311-322

Argaw A, Fikiresillassie M, Akuma A (2012a) Evaluation of selected isolates of Rhizobium Leguminosarum bv. vicea nodulating faba bean (Vicia faba L.) in Hararghe Highland. In: Urge M, Dechassa N, Ketema M, Yitayih M,
Animut G (eds) Proceedings of the 29th annual research and extension review workshop, 2011/2012. Haramaya University, pp 67-68

Argaw A, Fikiresillassie M, Akuma A (2012b) Evaluation of selected isolates of Rhizobium Leguminosarum bv. vicea Nodulating Field Pea (Pisum sativum L.) in Hararghe Highland. In: Urge M, Dechassa N, Ketema M, Yitayih M, Animut $G$ (eds) Proceedings of the 29th annual research and extension review workshop, 2011/2012. Haramaya University, pp 69-70

Barbour WM, Wang S, Stacy G (1992) Molecular genetics of Bradyrhizobium symbiosis. In: Stacy G, Burris RH, Evans HJ (eds) Biological nitrogen fixation. Chapman and Hall, New York, pp 649-684

Becana M, Sprent J (1987) Nitrogen fixation and nitrite reduction in the root nodules of legumes. Physiol Plant 70:757-776

Bianco L, Angelini J, Fabra A, Malpassi R (2013) Diversity and symbiotic effectiveness of indigenous Rhizobia-nodulating Adesmia bicolorin soils of Central Argentina. Curr Microbiol 66:174-184

Bogino P, Banchio E, Giordano W (2010) Molecular diversity of peanut-nodulating rhizobia in soils of Argentina. J Basic Microbiol 50:274-279

Brockwell J (1963) Accuracy of a plant-infection technique for counting populations of Rhizobium trifolii. Appl Microbiol 2:377-383

Castro S, Permigiani M, Vinocur M, Fabra A (1999) Nodulation in peanut (Arachis hypogaea L.) roots in the presence of native and inoculated rhizobia strains. Appl Soil Ecol 13:39-44

Chemining'wa GN, Vessey JK (2006) The abundance and efficacy of Rhizobium leguminosarum bv. viciae in cultivated soils of the eastern Canadian prairie. Soil Biol Biochem 38:294-302

Chen WX, Tan ZY, Gao JL, Li Y, Wang ET (1997) Rhizobium hainanense sp. nov., isolated from tropical legumes. Int J Syst Bacteriol 47:870-873

Chen Q, Zhang X, Terefework Z, Kaijalainen S, Li D, Lindström K (2003) Diversity and compatibility of peanut (Arachis hypogaea L.) bradyrhizobia and their host plants. Plant Soil 255:605-617

Deaker R, Roughley RJ, Kennedy IR (2004) Legume seed inoculation technology-a review. Soil Biol Biochem 36:1275-1288

Denton MD, Reeve WG, Howieson JG, Coventry DR (2003) Competitive abilities of common field isolate and a commercial strain of Rhizobium leguminosarum bv. Trifolii for clover nodule occupancy. Soil Biol Biochem 35:1039-1048

Denton MD, Pearce DJ, Ballard RA, Hannah MC, Mutch LA, Norng S, Slattery JF (2009) A multi-site field evaluation of granular inoculants for legume nodulation. Soil Biol Biochem 41:2508-2516

Douka CE, Xenoulis AC (1987) Nitrogen fixation by soybean in a Greek soil inoculated with an indigenous Rhizobium strain. Biol Agric Hortic 5:25-39

Drew EA, Denton MD, Sadras VO, Ballard RA (2012) Agronomic and environmental drivers of population size and symbiotic performance of Rhizobium leguminosarum bv. viciae in Mediterranean-type environments. Crop Pasture Sci 63:467-477

Elkan GH (1992) Biological nitrogen fixation. In: Lederberg J (ed) Encyclopedia of microbiology. Academic press, San Diego, pp 285-296

FAOSTAT (2014) http://www.fao.org/faostat/en/\#data/QC. Accessed Dec 2016

Hardarson G (1993) Methods for enhancing symbiotic nitrogen fixation. Plant Soil 152:1-17

Hitbold AE, Hartzog DL, Harrison RB, Adams F (1983) Inoculation of peanuts on farmers' fields in Alabama. Peanut Sci 10:79-82

Huang HQ (1987) The effect of Rhizobium inoculation on Tianfu peanut No.3. J Sichuan Agric Uni 5:191-195

Huang HQ, He FR, Chen ZH (1990) Study on the Biological Characteristic of fast-growing peanut rhizobial strains 85-7 and 85-19. J Sichuan Agric Uni 8:188-193

Hungria M, Nishi CYM, Cohn J, Stacey G (1996) Comparison between parental and variant soybean Bradyrhizobium strains with regard to the production of lipo-chitin nodulation signals, early stages of root infection, nodule occupancy, and $\mathrm{N}_{2}$ fixation rates. Plant Soil 186:331-341

Jones JB (2003) Agronomic handbook: management of crops, soils, and their fertility. CRC Press, Florida

Kebede A, Bushra F (2012) Registration of BaHa-jidu and BaHa-gudo Groundnut (Arachis hypogaea L.) varieties. East Afr J Sci 6(1):79-80

Kimiti JM, Odee DW (2010) Integrated soil fertility management enhances population and effectiveness of indigenous cowpea rhizobia in semi-arid eastern Kenya. Appl Soil Ecol 45:304-309

Kremer RJ, Peterson HL (1983) Field evaluation of selected Rhizobium in an improved legume inoculant. Agron J 75:139-143 
Kvien CS, Pallas JE (1986) Response of peanut to strains of Bradyrhizobium and N fertilizer. Commun Soil Sci Plant Anal 17(5):497-513

Li J, Xu LM, Fan H, Li L, Ge C, Yang SS (1999) Genetic diversity among Chinese peanut rhizobia by REP-PCR analysis. Acta Microbiol Sin 39:296-304

Lindström K, Murwira M, Willems A, Altier N (2010) The biodiversity of beneficial microbe-host mutualism: the case of rhizobia. Res Microbiol 161:453-463

Maj D, Wielbo J, Marek-Kozaczuk M, Skorupska A (2010) Response to flavonoids as a factor influencing competitiveness and symbiotic activity of Rhizobium leguminosarum. Microbiol Res 165:50-60

Makatiani ET, Odee DW (2007) Response of Sesbania sesban (L.) Merr. to rhizobial inoculation in an $\mathrm{N}$-deficient soil containing low numbers of effective indigenous rhizobia. Agroforest Syst 70:211-216

Moawad H, Badr El-Din SMS, Khalafallah M (1986) Quantification of nitrogen fixation by the peanut/Rhizobium symbiotic system in a virgin sandy soil. J Plant Nutr Soil Sci 149(6):668-673

Mpepereki S, Wollum AG, Makonese F (1996) Diversity in symbiotic specificity of cowpea rhizobia indigenous to Zimbabwean soils. Plant Soil 186:167-171

Nambiar PTC, Dart PJ (1980) Studies on nitrogen fixation by groundnut at ICRISAT. In: Gibbons RW (ed) Proc. int workshop on groundnut. Hyderabad, India, 13-17 Oct. 1980. ICRISAT Center, Patancheru, India, pp 110-124

Nambiar PTC, Dart PJ, Nigam SN, Gibbons RW (1982) Genetic manipulation of nodulation in groundnut. In: Graham PH, Harris SC (eds) Biological nitrogen fixation technology for tropical agriculture. CIAT, Cali, pp 49-56

Nelson LM (1987) Response of Rhizobium leguminosarum isolates to different forms of inorganic nitrogen during nodule development in pea (Pisum sativum L.). Soil Biol Biochem 19:759-763

Nievas F, Bogino P, Nocelli N, Giordano W (2012) Genotypic analysis of isolated peanut-nodulating rhizobial strains reveals differences among populations obtained from soils with different cropping histories. Appl Soil Ecol 53:74-82

Okito A, Rodrigues Alves BJ, Urquiaga S, Boddey RM (2004) Nitrogen fixation by groundnut and velvet bean and residual benefit to a subsequent maize crop. Pesqu Agropec Bras Brasilia 12:1183-1190

Okogun JA, Sanginga N (2003) Can introduced and indigenous rhizobial strains compete for nodule formation by promiscuous soybean in the moist savanna agroecological zone of Nigeria? Biol Fertil Soils 38:26-31

Peng GX, Tan ZY, Wang ET, Reinhold-Hurek B, Chen WF, Chen WX (2002) Identification of isolates from soybean nodules in Xinjiang region as Sinorhizobium xinjiangense and genetic differentiation of $S$. xinjiangense from Sinorhizobium fredii. Int J Syst Evolut Microb 52:457-462

Peoples MB, Bowman AM, Gault RR, Herridge DF, McCallum MH, McCormick KM, Norton RM, Rochester IJ, Scammell GJ, Schwenke GD (2001) Factors regulating the contributions of fixed nitrogen by pasture and crop legumes to different farming systems of eastern Australia. Plant Soil 228:29-41

Räsänen LA, Lindström K (1999) The effect of heat stress on the symbiotic interaction between Sinorhizobium sp. and Acacia Senegal. FEMS Microbiol Ecol 28:63-74

Sessitsch A, Howieson JG, Perret X, Antoun H, Martnez-Romero E (2002) Advances in Rhizobium research. Crit Rev Plant Sci 21:323-378

Somasegaran P, Hoben HJ (1994) Handbook for Rhizobia. Springer, New York

Tan ZY, Wang ET, Peng GX, Zhu ME, Martinez-Romero E, Chen WX (1999) Characterization of bacteria isolated from wild legumes in the north-western regions of China. Int J Syst Bacteriol 49:1457-1469
Taurian T, Ibañez F, Fabra A, Aguilar OM (2006) Genetic diversity of rhizobia nodulating Arachis hypogaea L. in Central Argentina soils. Plant Soil 282:41-52

Thies JE, Bohlool BB, Singleton PW (1991) Subgroups of the cowpea miscellany: symbiotic specificity within Bradyrhizobium spp. for Vigna unguiculata, Phaseolus lunatus, Arachis hypogaea and Macroptilium atropurpureumt. Appl Environ Microbiol 57(5):1540-1545

Thrall PH, Slattery JF, Broadhurst LM, Bickford S (2007) Geographic patterns of symbiont abundance and adaptation in native Australian acacia-rhizobia interactions. J Ecol 95:1110-1122

Valladares F, Villar-Salvador P, Dom'inguez S, Fernandez-Pascual M, Peñuelas JL, Pugnaire Fl (2002) Enhancing the early performance of the leguminous shrub Retama sphaerocarpa (L.) Boiss.: fertilisation versus Rhizobium inoculation. Plant Soil 240:253-262

van Rossum D, Muyotcha A, de Hoop BM, van Verseveld HW, Stouthamer AH, Boogerd FC (1994) Soil acidity in relation to groundnut-Bradyrhizobium symbiotic performance. Plant Soil 163:165-175

Vincent JM (1970) A manual for the practical study of the root-nodule bacteria. IBP. Handbook. No: 15. Blackwell Scientific Publications, Oxford.

Weaver RW (1974) Effectiveness of rhizobia forming nodules on Texas-grown peanuts. Peanut Sci 1:23-25

Wielbo J, Marek-Kozaczuk M, Kubik-Komar A, Skorupska A (2007) Increased metabolic potential of Rhizobium spp. is associated with bacterial competitiveness. Can J Microbiol 53:957-967

Wielbo J, Kidaj D, Koper P, Kubik-Komar A, Skorupska A (2012) The effect of biotic and physical factors on the competitive ability of Rhizobium leguminosarum. Central Eur J Biol 7(1):13-24

Willems A, Coopman R, Gillis M (2001) Phylogenetic and DNA-DNA hybridization analyses of Bradyrhizobium species. Int I Syst Evol Microbiol 51:111-117

Wollum AG (1998) Constrains and opportunities for biological nitrogen fixation in a challenging world. In: Mpepereki S, Makones F (eds) Harnessing biological nitrogen fixation in Africa, challenges and opportunities. Harare, Zimbabwe, pp 11-33

Xu LM, Ge C, Cui Z, Li J, Fan H (1995) Bradyrhizobium liaoningense sp. nov., isolated from the root nodules of soybeans. Int I Syst Bacteriol 45:706-711

Yang JK, Xie FL, Zou J, Zhou Q, Zhou JC (2005) Polyphasic characteristics of Bradyrhizobia isolated from nodules of peanut (Arachis hypogaea) in China. Soil Biol Biochem 37:141-153

Yousef AN, AL-Nassiri AS, AL-Azawi SK, Abdul-Hussaip N (1987) Abundance of peanut Rhizobium as affected by environmental conditions in Iraq. Soil Biol Biochem 19(4):391-396

Zhang XP, Nick G, Kaijalainen S, Terefework Z, Paulin L, Tighe SW, Graham PH, Lindström K (1999) Phylogeny and diversity of Bradyrhizobium strains isolated from the root nodules of peanut (Arachis hypogaea L.) in Sichuan, China. Syst Appl Microbiol 22:378-386

\section{Submit your manuscript to a SpringerOpen ${ }^{\circ}$ journal and benefit from:}

- Convenient online submission

- Rigorous peer review

- Open access: articles freely available online

- High visibility within the field

- Retaining the copyright to your article

Submit your next manuscript at $\boldsymbol{\nabla}$ springeropen.com 